\title{
Penerapan Metode STEM Berbasis Proyek untuk Meningkatkan Hasil dan Keaktifan Belajar Mata Pelajaran Sistem Kontrol Terprogram
}

\author{
Suroto ${ }^{1}$ \\ ${ }^{1}$ Teknik Otomasi, SMK Negeri 2 Depok, Yogyakarta, Indonesia \\ 1 pakroto313@gmail.com* \\ * corresponding author
}

\begin{tabular}{|c|c|}
\hline$A B S T R A C T$ & Article Info \\
\hline $\begin{array}{l}\text { This research aims to: (1) describe the syntax of the implementation STEM } \\
\text { project-based method, (2) find out the improvement of learning outcomes and } \\
\text { activeness students in the Sistem Kontrol Terprogram subject at SMK Negeri } 2 \\
\text { Depok Sleman. This research is a Classroom Action Research (CAR) which } \\
\text { conducted in two cycles. Data collection using test methods, observation, and } \\
\text { documentation. The results showed that the STEM project-based method } \\
\text { implementation could improve students' learning outcomes and activeness. The } \\
\text { learning outcome in the cognitive domain in cycle } 1 \text { obtained the percentage of } \\
\text { completeness of } 84.38 \% \text { and in cycle } 2 \text { was } 96.88 \% \text {, an increase of } 12.5 \% \text {. The } \\
\text { results of learning observations in the psychomotor domain, the percentage } \\
\text { completion in cycle } 1 \text { was } 93.75 \% \text { and in cycle } 2 \text { was } 93.75 \% \text {. The observation } \\
\text { results of students' activeness obtained a percentage in cycle } 1 \text { of } 76.82 \% \text { and } \\
\text { cycle } 2 \text { of } 81.25 \% \text {, an increase of } 4.43 \% \text {. }\end{array}$ & $\begin{array}{r}\text { Article history } \\
\text { Received: July } 30^{\text {th }}, 2021 \\
\text { Revised: Nov. } 17^{\text {th }}, 2021 \\
\text { Accepted: Nov. } 29^{\text {th }}, 2021 \\
\text { Keywords } \\
\text { Metode pembelajaran } \\
\text { STEM, } \\
\text { Pembelajaran berbasis } \\
\text { proyek, } \\
\text { Hasil belajar, } \\
\text { Keaktifan belajar. }\end{array}$ \\
\hline ABSTRAK & \\
\hline $\begin{array}{l}\text { Penelitian ini bertujuan untuk: (1) mendeskripsikan sintak penerapan metode } \\
\text { STEM berbasis proyek, (2) mengetahui peningkatan hasil belajar dan keaktifan } \\
\text { belajar peserta didik pada mata pelajaran Sistem Kontrol Terprogram kelas } 12 \\
\text { SMK Negeri } 2 \text { Depok Sleman. Penelitian ini merupakan Penelitian Tindakan } \\
\text { Kelas (PTK) yang dilaksanakan dalam dua siklus. Pengumpulan data dengan } \\
\text { metode tes, observasi dan dokumentasi. Hasil penelitian menunjukkan bahwa } \\
\text { penerapan metode STEM berbasis proyek dapat meningkatkan hasil belajar dan } \\
\text { keaktifan peserta didik. Hasil belajar ranah kognitif pada siklus } 1 \text { diperoleh hasil } \\
\text { persentase ketuntasan sebesar } 84,38 \% \text { dan siklus } 2 \text { sebesar } 96,88 \% \text { mengalami } \\
\text { peningkatan sebesar } 12,5 \% \text {. Hasil observasi pembelajaran ranah psikomotorik } \\
\text { persentase ketuntasan pada siklus } 1 \text { sebesar } 93,75 \% \text { dan siklus } 2 \text { sebesar } 93,75 \% \text {. } \\
\text { Hasil observasi keaktifan peserta didik memperoleh hasil persentase pada siklus } 1 \\
\text { sebesar } 76,82 \% \text { dan pada siklus } 2 \text { sebesar } 81,25 \% \text {, mengalami peningkatan } \\
\text { sebesar } 4,43 \% \text {. }\end{array}$ & \\
\hline
\end{tabular}

\section{PENDAHULUAN}

Sekolah Menengah Kejuruan (SMK) Negeri 2 Depok berada di wilayah Daerah Istimewa Yogyakarta yang memiliki banyak kompetensi keahlian. Kompetensi keahlian yang dilaksanakan di SMK Negeri 2 Depok menyesuaikan dengan permintaan masyarakat atau kebutuhan dunia kerja. Salah satu kompetensi keahlian yang dilaksanakan di SMK ini adalah Teknik Otomasi Industri 
yang di dalam struktur kurikulumnya terdapat mata pelajaran Sistem Kontrol Terprogram. Sistem Kontrol Terprogram memuat tiga kompetensi yaitu Mikrokontrol, Sistem Programmable Logic Controller (PLC) dan Sistem SCADA (Supervisory Control and Data Acquisition). Tiga kompetensi tersebut merupakan unsur utama dalam proses otomatisasi di industri. Hampir semua industri menengah ke atas sistem kendalinya menerapkan teknologi otomasi. Mata Pelajaran Sistem Kontrol Terprogram ini merupakan mata pelajaran yang membutuhkan logika yang tinggi sehingga guru dituntut lebih kreatif dalam proses pembelajaran. Ketersediaan media dan model pembelajaran menjadi faktor utama keberhasilan dari tujuan pembelajaran. Lingkungan serta ketersediaan seluruh komponen pendukung dapat menjadikan proses pembelajaran berjalan dengan lebih optimal. Kenyataannya media belajar pada program keahlian Teknik Otomasi Industri khususnya pada mata pelajaran Sistem Kontrol Terprogram masih sangat terbatas. Hal ini menyebabkan pembelajaran teori di bidang cukup mendominasi dibanding dengan pembelajaran praktik. Proses pembelajaran seperti ini berakibat hasil belajar dan keaktifan peserta didik kurang maksimal. Pada kondisi seperti ini untuk mencapai tujuan pembelajaran peran guru dalam memilih model pembelajaran sangat menentukan.

$$
\text { Penerapan model pembelajaran }
$$
merupakan salah satu usaha guru untuk menyampaikan materi mata pelajaran sehingga peserta didik mampu menyerap materi secara maksimal. Peserta didik akan menjadi paham dan memiliki keterampilan sesuai dengan tujuan pembelajaran. Penerapan model pembelajaran konvensional yang selama ini sering dilakukan akan menimbulkan kebosanan pada peserta didik. Sehingga guru perlu melaksanakan berbagai inovasi dalam penggunaan model pembelajaran.

Model pembelajaran berbasis proyek (project based learning) atau PjBL adalah model pembelajaran yang menggunakan proyek sebagai metode pembelajaran. Peserta didik akan bekerja secara nyata, sehingga dapat menghasilkan produk secara realistis (Mahanal, 2009). Model pembelajaran Project Based Learning awalnya dikembangkan oleh The George Lucas Education Foundation dan Dopplet, dengan langkah-langkah pembelajaran berdasarkan beberapa fase sebagai berikut (Kemdikbud, 2014:34): (1) penentuan pertanyaan mendasar (start with essential question), (2) menyusun perencanaan proyek (design project), (3) menyusun jadwal (create schedule), (4) memantau peserta didik dan kemajuan proyek (monitoring the students and progress of project), (5) Penilaian hasil (assess the outcome), (6) evaluasi pengalaman (evaluation the experience).

Metode STEM (Scince Technology Engineering and Mathematics) merupakan sebuah strategi pembelajaran yang masih baru di Indonesia. Karakteristik dari STEM adalah menekankan pada tahap/proses desain rekayasa atau merekayasa dengan lebih dikenal dengan Engineering Design Process (EDP). Proses ini mengasah kemampuan peserta didik dalam memecahkan permasalahan (problem solving) dalam dunia nyata (real world). Langkahlangkah dalam proses desain rekayasa (EDP) sebagai berikut: (1) Identifikasi masalah. (2) Bertukar pikiran (brainstrorm). (3) Merancang. (4) Membangun (build/construct). (5) Ujicoba. (6) Revisi. (7) Berbagi solusi/komunikasi.

Pelaksanaan pendekatan STEM dalam kegiatan pembelajaran akan saling terintegrasi satu dengan yang lain selama kegiatan pembelajaran. Masing-masing aspek dalam STEM mengambil bagian tersendiri dalam melaksanakan langkah-langkah pembelajaran. Pada pelaksanaannya pada pelajaran ataupun industri, terdapat beragam cara dalam praktik integrasi disiplin-disiplin ilmu STEM tersebut. Cara, pola dan derajat keterpaduan antara tiap disiplin ilmu dikategorikan ke dalam beberapa pola tertentu yang ditentukan oleh banyak faktor (Roberts, 2012 dalam Firman, 2016:1-5). Dalam perkembangannya ada tiga pola pendekatan pembelajaran STEM yang umum 
dikenal oleh komunitas Pendidikan. Pembeda utama dari ketiga pola pendekatan ini adalah pada ketersinambungan dan derajat penggunaan konten STEM, tiga pola ini dikenal dengan pola Silo, pola terinkoporasi (embedded) dan pola terintegrasi (integrated) (Roberts dan Cantu, 2012: 111- 118). Adapun langkah-langkah dari setiap pelaksanaan aspek STEM tersebut adalah sebagai berikut: (1) Aspek Science dalam pendekatan STEM menurut Hannover (2011) adalah keterampilan dalam menggunakan pengetahuan dan proses sains untuk memahami gejala alam dan memanipulasi gejala tersebut sehingga dapat dilaksanakan, (2) Aspek Technologi adalah keterampilan peserta didik untuk mengetahui bagaimana teknologi baru dapat dikembangkan, menggunakan teknologi, dan bagaimana teknologi tersebut memudahkan kerja manusia, (3) Aspek Engineering memiliki lima tahap fase dalam proses pembelajaran dan (4) Aspek Mathematics adalah keterampilan yang digunakan untuk menganalisis, memberikan alasan, mengkomunikasikan ide secara efektif, menyelesaikan masalah dan menginterpretasikan solusi berdasarkan perhitungan dan data dengan matematis. Strategi pembelajaran STEM merupakan strategi pembelajaran yang saat ini banyak dicoba diterapkan dalm proses pembelajaran oleh guru-guru di Indonesia.

Hasil belajar menurut Dimyati dan Mudjiono (2006:3) merupakan suatu proses untuk mengetahui peserta didik dapat menguasai pembelajaran setelah melaksanakan proses belajar mengajar, atau keberhasilan peserta didik setelah mengikuti kegiatan pembelajaran. Hal tersebut dapat ditandai dalam bentuk angka, huruf, atau simbol tertentu sesuai dengan kesepakatan. Dalam kegiatan pembelajaran hasil belajar merupakan dokumen yang sangat penting. Hasil belajar bagi guru merupakan sebuah informasi tentang keberhasilan peserta didik dan sekaligus informasi keberhasilan dari proses pembelajaran yang telah dilaksanakan. Hasil belajar bagi guru bisa menjadi landasan langkah perbaikan proses pembelajaran berikutnya. Keberhasilan belajar peserta didik sangat dipengaruhi oleh banyak faktor yang secara garis besar dapat dikelompokan menjadi dua bagian yaitu faktor internal dan faktor eksternal. Faktor internal berasal dari diri peserta didik yang dapat mempengaruhi keberhasilan belajar seperti kondisi kesehatan, fungsi dari panca indra dan keadaan fisik. Keadaan fisik yang lemah atau kurang sempurna dan tidak berfungsinya panca indra dapat menjadi penghalang peserta didik menyelesaikan program studinya (Mustaqim, 2001:70). Faktor eksternal adalah faktor yang berasal dari luar peserta didik yang dapat mempengaruhi keberhasilan belajar. Yang termasuk faktor eksternal diantaranya faktor lingkungan keluarga seperti kondisi ekonomi, pendidikan orang tua, pekerjaan orang tua dan hubungan antar anggota keluarga (Sumadi Suryabrata, 2002, 176).

Menurut Sudirman A.M, (2001:98) keaktifan merupakan kegiatan yang bersifat fisik maupun mental, yaitu berbuat dan berpikir sebagai suatu rangkaian yang tidak bisa dipisahkan. Kegiatan yang dimaksud dalam pengertian keaktifan adalah keaktifan peserta didik yang berkaitan dengan proses pembelajaran meliputi keberanian bertanya, mengajukan pendapat, menjawab pertanyaan guru, bekerja sama dengan peserta didik lain serta mengerjakan tugas dari guru. Keaktifan peserta didik dalam mengikuti proses pembelajaran dipengaruhi oleh dua faktor yaitu faktor internal dan faktor eksternal. Faktor internal berasal dari diri peserta didik yang mempengaruhi keaktifan belajar seperti kondisi kesehatan fisik dan kondisi psikologi peserta didik akan mempengaruhi aktivitas dalam proses pembelajaran. Menurut Sudirman A.M, (2001: 108) faktor psikologi yang mempengaruhi aktivitas belajar adalah perhatian, pengamatan, tanggapan, fantasi, ingatan, berpikir, bakat dan motif. Sedangkan faktor eksternal meliputi faktor keluarga, lingkungan sekolah, media pembelajaran, peralatan pembelajaran, dan upaya guru dalam 
menumbuhkan keaktifan peserta didik. Guru tidak menempatkan diri sebagai satu-satunya informan, tetapi berperan sebagai petunjuk dan fasilitator dalam memanfaatkan sumber belajar lainnya Wina Sanjaya (2010 :139). Cara menghitung persentase keaktifan peserta didik menurut Sugiyono (2001: 81) berdasarkan lembar observasi untuk tiap pertemuan adalah skor keseluruhan yang diperoleh kelompok dibagi dengan jumlah kelompok kali skor maksimum.

Berdasarkan uraian tersebut, maka guru tertarik mengadakan penelitian dengan memilih judul "Penerapan Metode STEM Berbasis Proyek untuk Meningkatkan Hasil dan Keaktifan Belajar Peserta didik Mata Pelajaran Sistem Kontrol Terprogram Kelas XII Kompetensi Keahlian Teknik Otomasi Industri SMK N 2 Depok".

\section{METODE}

Jenis penelitian yang dilakukan adalah penelitian tindakan kelas (Classroom Action Research) yang dilakukan secara kolaboratif dengan pendekatan kualitatif. Penelitian ini menggunakan metode pembelajaran STEM berbasis proyek. Adapun penelitian ini dilakukan dalam dua siklus dengan tahapan sebagai berikut: perencanaan (planning), tindakan (acting), pengamatan (observation) dan refleksi (reflecting). Kegiatan yang dilakukan dalam setiap tahapan diantaranya adalah:

1. Tahapan Perencanaan (Panning)

Kegiatan dalam tahapan ini meliputi:

a. Observasi proses pembelajaran mata pelajaran Sistem Kontrol Terprogram di kelas untuk mengetahui kondisi yang nyata.

b. Mengidentifikasi permasalahan temuan hasil observasi proses pembelajaran mata pelajaran Sistem Kontrol Terprogram.

c. Menyiapkan instrumen/perangkat yang digunakan dalam penelitian yaitu silabus, rencana pelaksanaan pembelajaran, lembar kerja peserta didik, lembar observasi keaktifan peserta didik, lembar observasi pelaksanaan pembelajaran metode STEM berbasis Proyek.

2. Tahapan Tindakan (Acting)

Kegiatan pada tahapan ini guru sebagai peneliti melaksanakan pembelajaran dengan metode STEM berbasis proyek sesuai dengan rencana pelaksanaan pembelajaran (RPP) dan dilaksanakan sesuai jadwal pelajaran. Dalam kegiatan proses pembelajaran guru dibantu observer melakukan observasi. Guru melakukan tindakan perbaikan terhadap proses pembelajaran apabila ditemukan hal-hal yang kurang dari hasil observasi/ pengamatan.

3. Tahapan Pengamatan (Observing)

Pada tahapan ini selama proses pembelajaran berlangsung melakukan observasi/pengamatan dengan lembar observasi yang telah disiapkan. Pengamatan meliputi aktivitas guru dan aktivitas peserta didik dan mencatat kejadian-kejadian yang tidak terdapat pada lembar observasi dengan membuat lembar catatan lapangan.

4. Tahapan Refleksi (Reflecting)

Pada tahapan refleksi, guru dan observer melakukan evaluasi dari pelaksanaan tindakan pada siklus I yang digunakan sebagai bahan pertimbangan perencanaan proses belajar mengajar siklus berikutnya. Jika hasil yang diharapkan belum bisa tercapai maka dilakukan perbaikan pada pelaksanaan siklus berikutnya.

Teknik pengumpulan data yang digunakan dalam penelitian ini adalah tes (pre test dan post test), observasi (lembar observasi keaktifan peserta didik, lembar observasi pelaksanaan pembelajaran metode STEM berbasis proyek dan lembar observasi untuk penilaian aspek psikomotorik), dokumen (fotofoto selama proses pembelajaran berlangsung, hasil observasi, hasil tes dan catatan lapangan). 
Hasil penelitian dianalisis menggunakan metode deskriptif kualitatif dengan mempertimbangkan kriteria atau indikator keberhasilan yang telah ditetapkan. Kriteria keberhasilan yang ditetapkan adalah sebagai berikut: (1) Aspek kognitif dikatakan tuntas apabila nilai tes hasil belajar peserta didik minimal $80 \%$ peserta didik lulus dengan kriteria ketuntasan minimal sekolah sebesar 75. (2) Aspek psikomotor dikatakan tuntas apabila nilai tes peserta didik minimal $80 \%$ peserta didik lulus dengan kriteria ketuntasan minimal sekolah sebesar 75. (3) Aspek keaktifan peserta didik dikatakan berhasil apabila persentase skor keaktifan peserta didik minimal $80 \%$.

\section{HASIL DAN PEMBAHASAN}

Penerapan pendekatan STEM dalam pembelajaran tentunya terintegrasi selama proses pembelajaran berlangsung. Keempat aspek dalam STEM mengambil bagian dalam setiap pelaksanaan langkah-langkah pembelajaran (Hannover, 2011). Implementasi STEM dalam proses pembelajaran berbasis proyek mata pelajaran Sistem Kontrol Terprogram pada kompetensi dasar melakukan komisioning dan pengujian pada sistem kontrol dengan PLC sebagai berikut:

\section{- Scince}

1) Faktual: Bila tombol ditekan motor listrik akan berputar

2) Konseptual: Hukum Ohm, Rangkaian listrik, (Besar arus, tegangan, pengaman)

3) Prosedural: SOP merangkai komponen listrik, SOP Pengujian rangkaian listrik

\section{- Technology}

1) Komputer untuk mendesain program dan simulasi kerja motor listrik

2) Komponen rangkaian listrik (lampu, kabel, MC, MCB, TOR, Motor Listrik, PLC)

\section{- Engineering}

1) Mendesain gambar rangkaian

2) Mendesain program

3) Merangkai komponen listrik

4) Menguji coba rangkaian

\section{- Mathematics}

1) Ukuran-ukuran komponen

2) Mengukur besaran-besaran kelistrikan

3) Menentukan ukuran pengaman

4) Logika input/output (I/O)

Adapun sintak penerapan metode STEM berbasis proyek pada penelitian ini adalah sebagai berikut: (1) penentuan pertanyaan mendasar, pada langkah guru memberikan pertanyaan dan permasalahan kontrol yang berkaitan komisioning dan pengujian sistem kontrol dengan PLC, (2) menyusun perencanaan proyek (design project), pada langkah ini guru dan peserta didik menyusun perencanaan kegiatan untuk menyelesaikan permasalahan yang berkaitan dengan komisioning dan pengujian sistem kontrol dengan PLC. Peserta didik dilibatkan dalam perencanaan kegiatan, agar peserta didik merasa memiliki atas proyek tersebut, (3) menyusun jadwal, pada langkah ini guru dan peserta didik menyusun jadwal kegiatan dalam menyelesaikan proyek, (4) memantau peserta didik dan kemajuan proyek (monitoring the students and progress of project), pada langkah ini guru memantau peserta didik dalam berdiskusi dan kegiatan lain dalam menyelesaikan proyek, (5) penilaian hasil (assess the outcome), guru menilai sikap dan keterampilan peserta didik dalam kegiatan penyelesaian proyek (6) evaluasi pengalaman (evaluation the experience), guru dan peserta didik melakukan refleksi terhadap terhadap kegiatan dan hasil proyek yang sudah dijalankan.

Penelitian ini dilaksanakan dalam dua tahap, tahap pertama yaitu sebelum dilakukan tindakan pada kelas XII TOIB disebut pra siklus dan tahap sesudah dilakukan tindakan siklus. Tahap tersebut dianggap mampu memenuhi kriteria keberhasilan tindakan dalam mencapai hasil yang diinginkan dan mengatasi persoalan atau temuan yang ada. Penelitian ini dilaksanakan dalam dua siklus. Hasil penelitian dan pembahasannya masing-masing siklus sebagai berikut. 


\section{Pra Siklus}

Hasil yang diperoleh dari pra siklus atau sebelum dilakukan tindakan dengan instrumen lembar observasi adalah data keaktifan peserta didik dan prestasi belajar ranah psikomotorik serta prestasi belajar ranah kognitif melalui tes. Data keaktifan peserta didik dapat ditunjukan dalam diagram batang seperti Gambar 1.

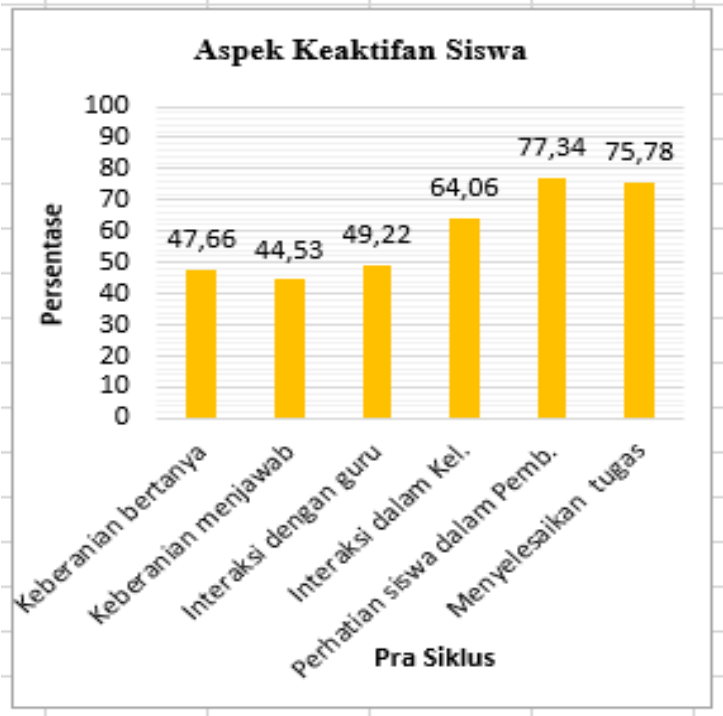

Gambar 1. Data Keaktifan Peserta didik Pra Siklus

Gambar 1 menunjukkan bahwa persentase aspek keberanian bertanya memperoleh skor $47,66 \%$, aspek keberanian menjawab memperoleh skor 44,53\%, aspek interaksi dengan guru memperoleh skor $49,22 \%$, aspek interaksi dalam kelompok memperoleh skor $64,06 \%$, aspek perhatian peserta didik selama proses pembelajaran memperoleh skor $77,34 \%$, dan aspek menyelesaikan soal dan tugas memperoleh skor $75,78 \%$. Secara keseluruhan kriteria keaktifan peserta didik pada tahapan pra siklus dengan persentase $59,77 \%$ tergolong sedang. Dari data tersebut menunjukkan bahwa keberanian peserta didik menjawab pertanyaan guru dan keberanian menjawab masih rendah, hasil ini digunakan sebagai masukan pada siklus berikutnya.

Hasil belajar ranah psikomotorik diperoleh dengan instrumen lembar observasi pembelajaran praktik yang terdiri dari aspek persiapan kerja, aspek proses kerja, aspek hasil kerja, aspek sikap kerja dan aspek waktu. Hasil belajar ranah psikomotorik pada pra tindakan diperoleh hasil aspek persiapan kerja 87,50\%, aspek proses kerja $81,25 \%$, aspek hasil kerja $86,56 \%$, aspek sikap kerja $81,02 \%$ dan aspek waktu $71,25 \%$. Persentase tingkat ketuntasan $81,25 \%$ dengan rata-rata 81,50 , nilai terendah 72 dan nilai tertinggi 92. Kemudian melalui instrumen tes diperoleh hasil belajar aspek pengetahuan/kognitif nilai terendah 48 , nilai tertinggi 82, tingkat ketuntasan 59,38 dengan rata-rata 71,94 . Persentase tingkat ketuntasan aspek kognitif, psikomotorik dan keaktifan peserta didik dapat ditunjukkan dalam diagram batang seperti Gambar 2.

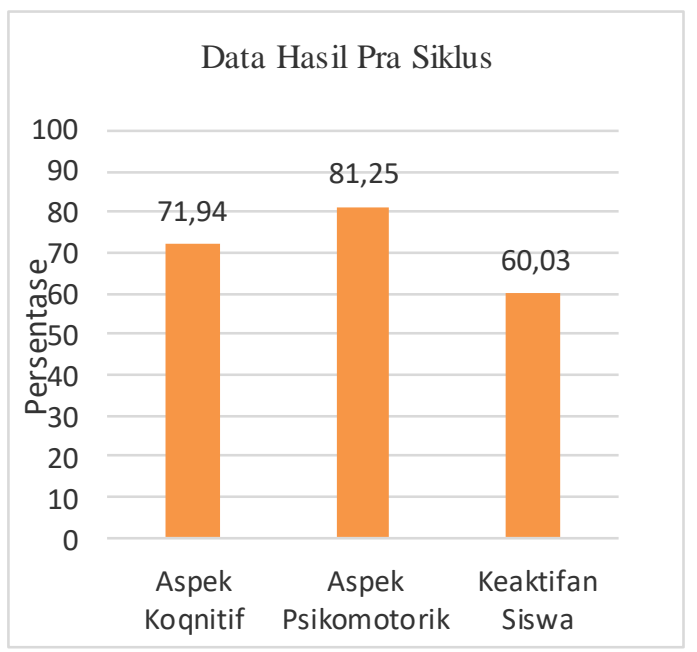

Gambar 2. Persentase Hasil Pra Siklus

\section{Siklus 1}

Dengan menggunakan instrumen tes diperoleh data hasil belajar peserta didik ranah kognitif (pengetahuan). Hasil belajar peserta didik ranah kognitif sebagai berikut: persentase ketuntasan belajar $84,38 \%$, nilai terendah 72 , nilai tertinggi 90 dan nilai rata-rata kelas 81,50. Dengan hasil ini persentase ketuntasan belajar sudah tercapai tetapi tetap dilanjutkan siklus 2 untuk memperoleh hasil yang lebih maksimal lagi.

Dari pelaksanaan tindakan siklus 1 dengan menggunakan lembar observasi diperoleh hasil data keaktifan peserta didik dan 
hasil belajar peserta didik ranah psikomotorik. Dari siklus 1 yang telah dilaksanakan diperoleh data persentase keaktifan peserta didik aspek keberanian bertanya memperoleh skor $65,63 \%$, aspek keberanian menjawab memperoleh skor $63,28 \%$, aspek interaksi dengan guru memperoleh skor 91, aspek interaksi dalam kelompok memperoleh skor 71,09\%, aspek perhatian peserta didik selama proses pembelajaran $95,31 \%$ dan aspek menyelesaikan soal atau tugas memperoleh skor $91,41 \%$. Data keaktifan peserta didik dapat ditunjukkan dalam diagram batang seperti gambar berikut.

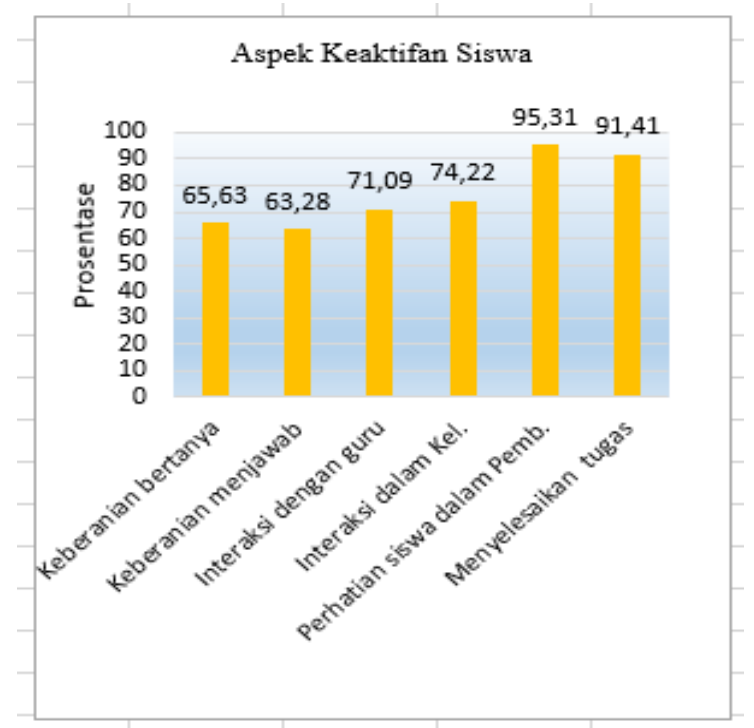

Gambar 3. Data Keaktifan Peserta didik Siklus 1

Gambar 3. menunjukkan bahwa skor perolehan aspek keberanian bertanya dan aspek keberanian menjawab pertanyaan atau menyampaikan pendapat dibanding dengan hasil pra siklus terjadi peningkatan yang signifikan. Persentase keaktifan peserta didik pada siklus 1 diperoleh hasil $76,82 \%$ berarti termasuk kriteria tinggi tetapi belum memenuhi kriteria keberhasilan belajar. Skor perolehan aspek keaktifan peserta didik pada siklus 1 bila dibandingkan dengan skor maksimal setiap aspek keaktifan sebesar 128 maka skor perolehan semua aspek keaktifan peserta didik diupayakan agar bisa meningkat pada siklus 2 .
Adapun hasil belajar peserta didik ranah psikomotorik pada siklus 1 diperoleh hasil sebagai berikut: aspek persiapan 92,50\%, aspek proses 82,19\%, aspek hasil 94,06\%, aspek sikap kerja 83,36\% dan aspek waktu $77,50 \%$. Nilai terendah 74, nilai tertinggi 96 dan nilai rata-rata 84,13 . Kriteria ketuntasan belajar ranah psikomotorik 93,75\%. Capaian setiap aspek dari instrumen lembar observasi hasil pembelajaran ranah psikomotorik dapat digambarkan dengan diagram batang seperti Gambar 4.

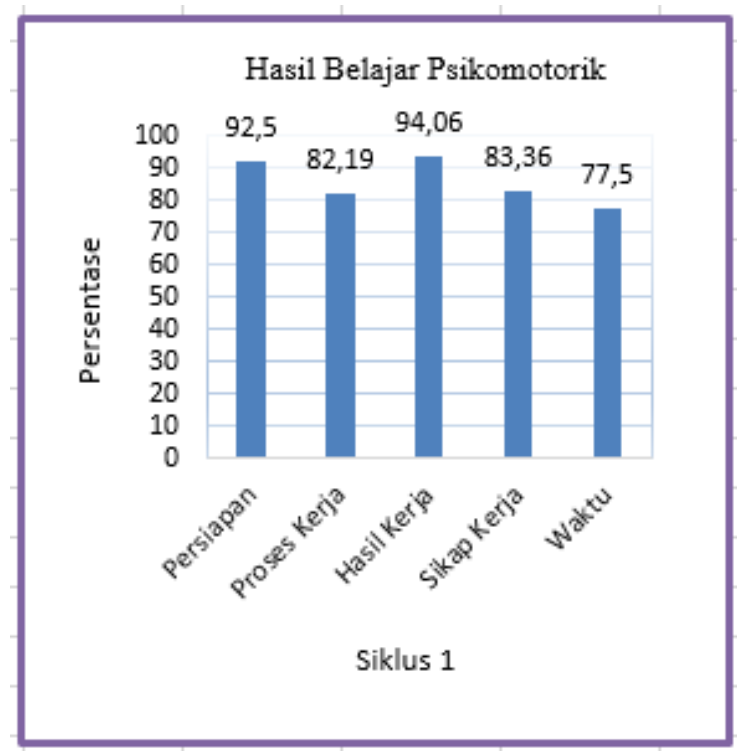

Gambar 4. Hasil Belajar Psikomotorik Siklus 1

Dari hasil belajar ranah psikomotorik diatas menunjukkan bahwa capaian setiap aspek dari instrumen lembar observasi semua diatas ketuntasan minimal dan persentase ketuntasan belajar juga sudah diatas ketuntasan minimal. Perbandingan hasil belajar ranah kognitif, psikomotorik dan keaktifan peserta didik pada siklus1 dapat digambarkan dengan diagram batang seperti Gambar 5 . 


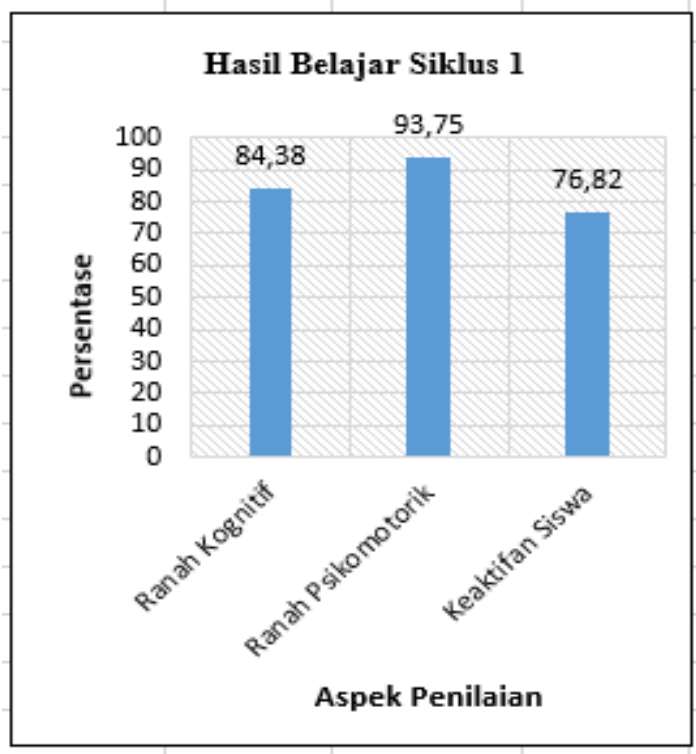

Gambar 5. Hasil Belajar Siklus 1

Dari data hasil tindakan siklus 1 dapat disimpulkan bahwa hasil belajar ranah kognitif dan psikomotorik sudah memenuhi kriteria keberhasilan tindakan yang telah ditetapkan yaitu ketuntasan minimal $80 \%$. Sedangkan data keaktifan peserta didik meskipun sudah masuk kategori tinggi tetapi belum memenuhi kriteria keberhasilan tindakan yaitu $80 \%$. Selanjutnya akan dilaksanakan tindakan siklus 2 untuk mendapatkan data yang lebih kuat dan untuk meningkatkan keaktifan peserta didik agar bisa memenuhi kriteria keberhasilan tindakan yang telah ditetapkan.

\section{Siklus 2}

Tindakan siklus 2 dilaksanakan dengan memperhatikan temuan maupun catatan pada siklus1. Dari hasil keaktifan peserta didik aspek keberanian bertanya dan keberanian menjawab ataupun menyampaikan pendapat perlu ditingkatkan dengan cara mendorong peserta didik dan memberi pancingan agar semua peserta didik berani bahkan biasa untuk bertanya dan juga menjawab pertanyaan maupun menyampaikan pendapatnya ketika proses pembelajaran maupun ketika berdiskusi dikelompoknya.

Hasil pelaksanaan tindakan siklus 2 seperti siklus sebelumnya diperoleh hasil data keaktifan peserta didik dan hasil belajar. Data keaktifan peserta didik dan hasil belajar ranah psikomotorik diperoleh dengan instrumen lembar observasi. Data keaktifan peserta didik hasil tindakan siklus 2 dapat digambarkan dengan diagram batang sebagai berikut.

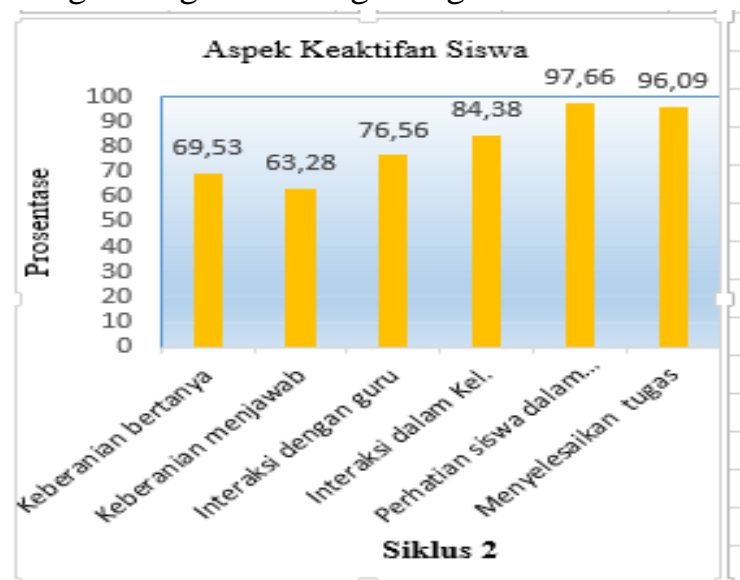

Gambar 6. Data Keaktifan Peserta didik Siklus

2

Dari Gambar 6 dapat dilihat bahwa keaktifan peserta didik aspek keberanian bertanya memperoleh persentase sebesar $69,53 \%$, aspek keberanian menjawab maupun menyampaikan pendapat memperoleh persentase 63,28\%, aspek interaksi dengan guru memperoleh persentase $76,56 \%$, aspek interaksi dalam kelompok memperoleh persentase $84,38 \%$, aspek perhatian peserta didik dalam proses pembelajaran memperoleh persentase 97,66\% dan aspek menyelesaikan soal dan tugas memperoleh persentase $96,09 \%$.

Ada dua aspek keaktifan peserta didik yang persentasenya masih di bawah $75 \%$ yaitu aspek keberanian bertanya dan menjawab pertanyaan maupun menyampaikan pendapat. Persentase keaktifan peserta didik pada siklus 2 diperoleh hasil $81,25 \%$ berarti termasuk kriteria sangat tinggi dan sudah memenuhi kriteria keberhasilan belajar. Hal ini juga membuktikan bahwa penerapan metode STEM berbasis proyek bisa meningkatkan keaktifan peserta didik dalam proses pembelajaran.

Hasil belajar ranah psikomotorik tindakan siklus 2 dapat digambarkan dengan diagram batang seperti Gambar 7 . 


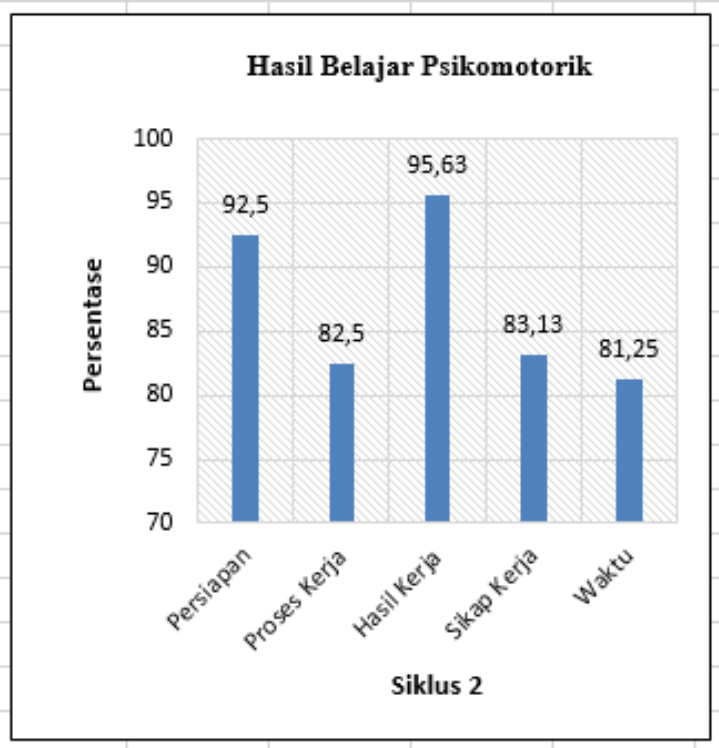

Gambar 7. Hasil Belajar Psikomotorik Siklus 2

Dari Gambar 7 dapat dilihat bahwa aspek persiapan kerja memperoleh persentase 92,50\%, aspek proses kerja memperoleh persentase $82,50 \%$, aspek hasil kerja memperoleh persentase $95,63 \%$, aspek sikap kerja memperoleh persentase $83,13 \%$ dan aspek waktu memperoleh persentase $81,25 \%$. Nilai terendah 74, nilai tertinggi 96 dan nilai rata-rata 84,63 . Kriteria ketuntasan belajar ranah psikomotorik 93,75\%. Bila dibandingkan dengan hasil pada tindakan siklus 1 untuk nilai terendah, nilai tertinggi dan kriteria ketuntasan belajar sama, yang terjadi peningkatan pada nilai rata-rata.

Selanjutnya dari tindakan siklus 2 diperoleh hasil belajar peserta didik ranah kognitif dengan persentase ketuntasan 96,88\%, nilai terendah 76 , nilai tertinggi 90 dan nilai rata-rata 84,31 . Dari data hasil belajar peserta didik ranah kognitif pada tindakan siklus 2 persentase ketuntasan sebesar $96,88 \%$ bila dibandingkan dengan hasil pada siklus 1 mengalami peningkatan yang signifikan. Nilai rata-rata pada siklus 2 sebesar 84,31 juga mengalami peningkatan dibanding hasil pada siklus 1. Hasil pada siklus 2 ini sekaligus memenuhi kriteria keberhasilan tindakan yang telah ditetapkan yaitu aspek kognitif dikatakan tuntas apabila nilai tes hasil belajar peserta didik minimal $80 \%$ peserta didik lulus dengan kriteria ketuntasan minimal sekolah sebesar 75 . Hasil tindakan siklus 2 meliputi keaktifan peserta didik, ranah psikomotorik dan ranah kognitif dapat digambarkan dengan diagram batang sebagai berikut.

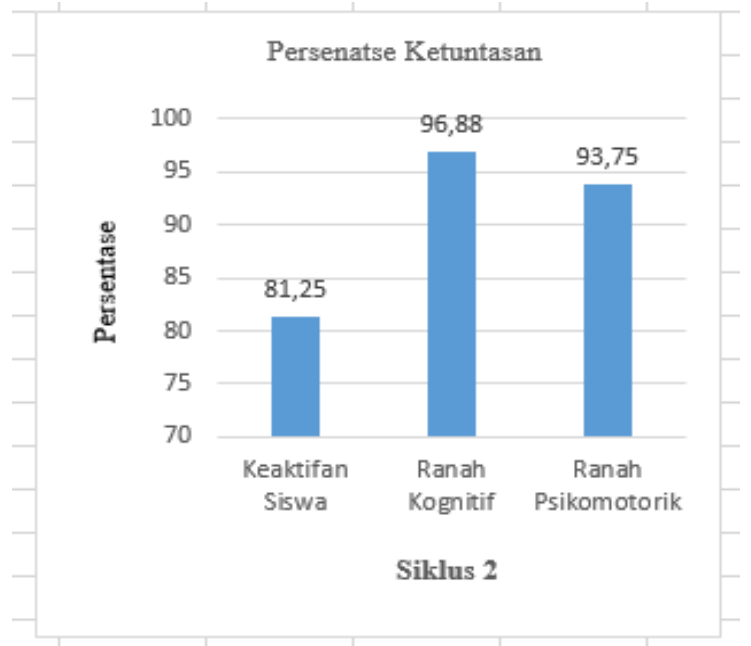

Gambar. 8. Hasil Keaktifan peserta didik, Ranah Kognitif, Ranah Psikomotorik Siklus 2

Dari Gambar 8 dapat dilihat bahwa aspek persentase keaktifan peserta didik sebesar $81,25 \%$, persentase ketuntasan aspek kognitif sebesar 96,88\%, persentase ketuntasan aspek psikomotorik sebesar 93,75\%. Dengan hasil siklus 2 seperti tersebut diatas berarti sudah memenuhi kriteria keberhasilan tindakan yang sudah ditetapkan yaitu minimal $80 \%$.

Dengan data tersebut sudah terbukti bahwa metode pembelajaran STEM berbasis proyek dapat meningkatkan hasil belajar dan keaktifan peserta didik pada mata pelajaran Sistem Kontrol Terprogram di SMK Negeri 2 Depok sehingga siklus dihentikan.

Setelah dilakukan tindakan sampai siklus 2 dapat diketahui perkembangan hasil belajar dari pra siklus sampai siklus 2 atau siklus terakhir. Perkembangan hasil keaktifan peserta didik dalam proses pembelajaran dapat ditunjukkan dengan gambar diagram batang seperti Gambar 9. 


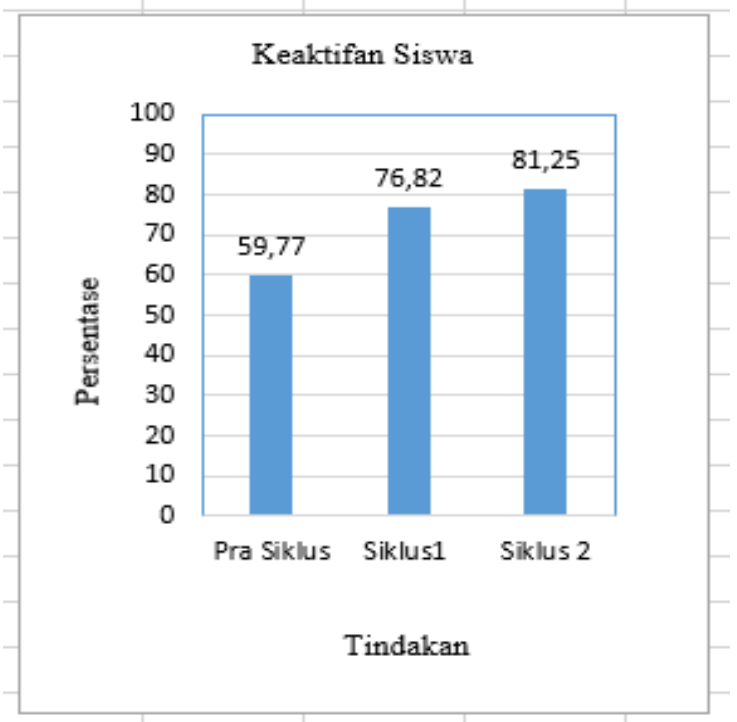

Gambar. 9 Perkembangan Hasil Keaktifan Peserta didik

Dari gambar diatas dapat dijelaskan bahwa persentase keaktifan peserta didik pada pra siklus sebesar 59,77\%, pada siklus1 sebesar 76,82\% dan pada siklus 2 sebesar 81,25\%.

Perkembangan persentase ketuntasan hasil belajar peserta didik ranah kognitif pada pra siklus sebesar 59,38\%, pada siklus 1 sebesar $84,38 \%$ dan pada siklus 2 sebesar $96,88 \%$. Dari data tersebut dapat ditunjukkan dengan gambar diagram batang sebagai berikut.

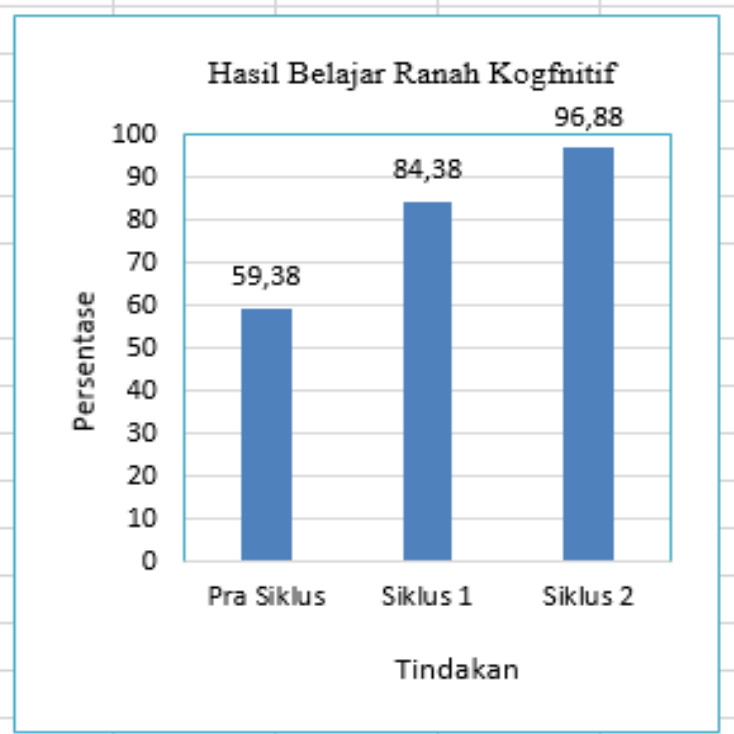

Gambar 10. Perkembangan Hasil Ranah Kognitif
Perkembangan persentase ketuntasan hasil belajar peserta didik ranah psikomotorik dapat ditunjukkan dengan gambar diagram batang sebagai berikut.

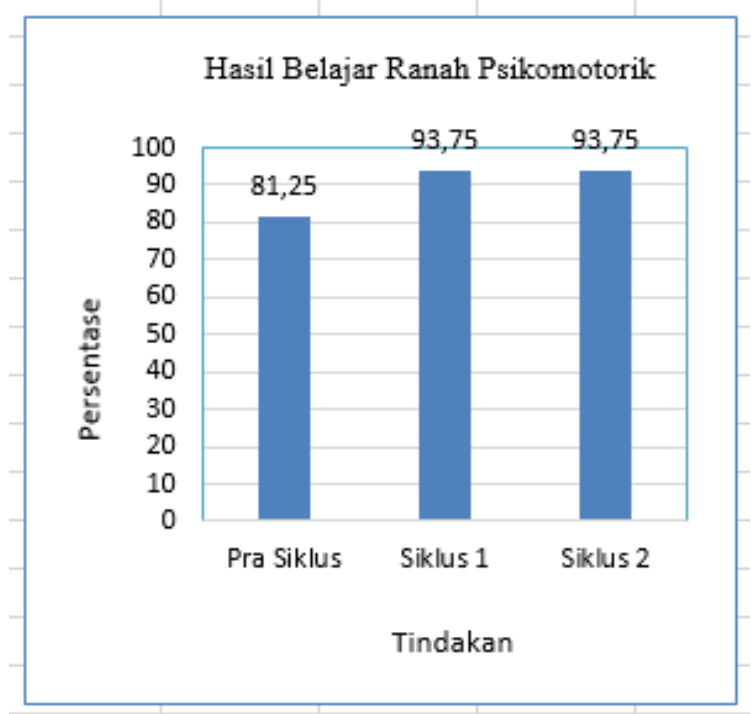

Gambar 11. Perkembangan Hasil Ranah Psikomotorik

Gambar 11 menunjukkan bahwa persentase ketuntasan belajar peserta didik ranah psikomotorik pada pra siklus sebesar $81,25 \%$, pada siklus 1 sebesar $93,75 \%$ dan pada siklus 2 sebesar $93,75 \%$. Persentase ketuntasan pada siklus 1 dan siklus 2 sama tetapi terjadi peningkatan pada nilai rata-rata dari 84,13 menjadi 84,63 .

\section{SIMPULAN}

Berdasarkan hasil penelitian dan pembahasan dapat disimpulkan sebagai berikut: (1) Penerapan metode STEM berbasis proyek dapat meningkatkan keaktifan peserta didik pada mata pelajaran Sistem Kontrol Terprogram pada kompetensi keahlian Teknik Otomasi Industri SMK Negeri 2 Depok Sleman. Dari observasi keaktifan peserta didik dalam proses pembelajaran diperoleh hasil ratarata persentase keaktifan peserta didik pada 
pra siklus atau sebelum tindakan sebesar $59,77 \%$, pada siklus 1 sebesar 76,82 dan pada siklus 2 sebesar 81,25\%. Besar peningkatan rata-rata persentase keaktifan peserta didik dari pra siklus dan siklus 1 sebesar $17,05 \%$, dari siklus 1 dan siklus 2 sebesar $4,43 \%$.

(2) Penerapan metode STEM berbasis proyek dapat meningkatkan hasil belajar peserta didik ranah kognitif atau pengetahuan pada mata pelajaran Sistem Kontrol Terprogram pada kompetensi keahlian Teknik Otomasi Industri SMK Negeri 2 Depok Sleman. Dengan tes diperoleh hasil belajar peserta didik persentase ketuntasan ranah kognitif pada pra siklus sebesar 59,38\% dengan rata-rata sebesar 71,94, pada siklus 1 sebesar $84,38 \%$ dengan rata-rata sebesar 81,50 dan pada siklus 2 sebesar 96,88\% dengan rata-rata sebesar 84,31. Besar peningkatan persentase ketuntasan ranah kognitif dari pra tindakan, ke siklus 1 sebesar 25,01\%, dari siklus 1 ke siklus 2 sebesar 12,50\%.

(3) Penerapan metode STEM berbasis proyek dapat meningkatkan hasil belajar siswa ranah psikomotorik atau keterampilan pada mata pelajaran Sistem Kontrol Terprogram pada kompetensi keahlian Teknik Otomasi Industri SMK Negeri 2 Depok Sleman. Dari observasi menggunakan lembar kerja siswa (LKS) diperoleh hasil belajar peserta didik ranah psikomotorik rata-rata persentase ketuntasan pada pra tindakan sebesar $81,25 \%$ dengan rata-rata sebesar 81,50, pada siklus 1 sebesar $93,75 \%$ dengan ratarata sebesar 84,13 dan pada siklus 2 sebesar 93,75\% dengan rata-rata sebesar 84,63. Besar peningkatan rata-rata persentase ketuntasan ranah psikomotorik dari pra tindakan ke siklus 1 sebesar $12,50 \%$, dari siklus 1 ke siklus 2 tidak terjadi peningkatan tetapi hanya terjadi peningkatan nilai rata-rata sebesar 0,5 .

\section{DAFTAR RUJUKAN}

Bybee, R.W. (2013). The Case for STEM Education; Challenges and Opportunity. National Science Teachers Association (NSTA) Press, Arlington, VI.

Dimyati dan Mudjiono (2006) Belajar dan Pembelajaran. Jakarta: Rineka Cipta, cet.3

Hanover Research (2011). K-12 STEM education overview

Kemdikbud (2019) Implementasi Pendekatan Pembelajaran Berbasis STEM Bagi Guru $S M K$. PPPPTK BOE

Mustaqim (2001) Psikologi Pendidikan. Yogyakarta: Pustaka Pelajar

Roberts, A. (2012) A justification for STEM education. Technology and Engineering Teacher, 74(8)

Roberts, A \& Cantu, D.(2012) Applying STEM instructional strategies to design and technology curriculum. Technology Education in the 21st Century, (73).

Sudirman A,M. (2001) Interaksi dan Motivasi Belajar Mengajar. Jakarta: PT. Raja Grafindo Persada

Sugiyono (2001) Metode Penelitian Administrasi. Bandung: Alfabeta

Sumadi Suryabrata (2002) Psikologi Pendidikan. Jakarta: Rajawali Press

Wina Sanjaya (2010) Strategi Pembelajaran Beroerntasi Standar Proses Pendidikan. Jakarta: Prenada Media Group. 